\title{
Effects of aerosols on clear-sky solar radiation in the ALADIN-HIRLAM NWP system
}

\author{
Emily Gleeson $^{1}$, Velle Toll ${ }^{2,3}$, Kristian Pagh Nielsen ${ }^{4}$, Laura Rontu ${ }^{5}$, and Ján Mašek ${ }^{6}$ \\ ${ }^{1}$ Research, Environment and Applications Division, Met Éireann, Dublin, Ireland \\ ${ }^{2}$ Institute of Physics, University of Tartu, Tartu, Estonia \\ ${ }^{3}$ Numerical Modelling Department, Estonian Environment Agency, Tallinn, Estonia \\ ${ }^{4}$ Department of Research and Development, Danish Meteorological Institute, Copenhagen, Denmark \\ ${ }^{5}$ Meteorological Research Department, Finnish Meteorological Institute, Helsinki, Finland \\ ${ }^{6}$ Department of Meteorology and Climatology, Czech Hydrometeorological Institute, Prague, Czech Republic \\ Correspondence to: Emily Gleeson (emily.gleeson@met.ie)
}

Received: 2 October 2015 - Published in Atmos. Chem. Phys. Discuss.: 19 November 2015

Revised: 14 March 2016 - Accepted: 25 April 2016 - Published: 17 May 2016

\begin{abstract}
The direct shortwave radiative effect of aerosols under clear-sky conditions in the Aire Limitee Adaptation dynamique Developpement InterNational - High Resolution Limited Area Model (ALADIN-HIRLAM) numerical weather prediction system was investigated using three shortwave radiation schemes in diagnostic single-column experiments: the Integrated Forecast System (IFS), acraneb2 and the hlradia radiation schemes. The multi-band IFS scheme was formerly used operationally by the European Centre for Medium Range Weather Forecasts (ECMWF) whereas hlradia and acraneb2 are broadband schemes. The former is a new version of the HIRLAM radiation scheme while acraneb2 is the radiation scheme in the ALARO-1 physics package.

The aim was to evaluate the strengths and weaknesses of the numerical weather prediction (NWP) system regarding aerosols and to prepare it for use of real-time aerosol information. The experiments were run with particular focus on the August 2010 Russian wildfire case. Each of the three radiation schemes accurately (within $\pm 4 \%$ at midday) simulates the direct shortwave aerosol effect when observed aerosol optical properties are used. When the aerosols were excluded from the simulations, errors of more than $+15 \%$ in global shortwave irradiance were found at midday, with the error reduced to $+10 \%$ when standard climatological aerosols were used. An error of $-11 \%$ was seen at midday if only observed aerosol optical depths at $550 \mathrm{~nm}$, and not observation-based spectral dependence of aerosol opti-
\end{abstract}

cal depth, single scattering albedos and asymmetry factors, were included in the simulations. This demonstrates the importance of using the correct aerosol optical properties. The dependency of the direct radiative effect of aerosols on relative humidity was tested and shown to be within $\pm 6 \%$ in this case. By modifying the assumptions about the shape of the IFS climatological vertical aerosol profile, the inherent uncertainties associated with assuming fixed vertical profiles were investigated. The shortwave heating rates in the boundary layer changed by up to a factor of 2 in response to the aerosol vertical distribution without changing the total aerosol optical depth. Finally, we tested the radiative transfer approximations used in the three radiation schemes for typical aerosol optical properties compared to the accurate DISORT model. These approximations are found to be accurate to within $\pm 13 \%$ even for large aerosol loads.

\section{Introduction}

The direct radiative effect of aerosols resulting from scattering and absorption of electromagnetic radiation at shortwave (SW) and longwave (LW) wavelengths has an impact on the Earth's radiation budget (e.g. Haywood and Boucher, 2000; Bellouin et al., 2005; Jacobson, 2001; Myhre et al., 2013; Yu et al., 2006; Loeb and Manalo-Smith, 2005) and on meteorology (e.g. Cook and Highwood, 2004; Takemura et al., 2005; Wang, 2004; Mulcahy et al., 2014; Bangert et al., 2012) 
which needs to be accounted for in numerical weather prediction (NWP) models. Climatological distributions of aerosols are commonly used in present-day operational NWP models for calculating the direct radiative effect of aerosols.

Using unrealistic aerosol distributions can lead to considerable errors in meteorological forecasts. Milton et al. (2008) showed that excluding the direct radiative effect of mineral dust and biomass burning aerosols in forecasts using the UK Met Office Unified Model during the dry season in West Africa, resulted in an inaccurate representation of the surface energy budget and a warm bias in screen level temperature. Carmona et al. (2008) presented significant correlations between errors in the aerosol optical depth (AOD) assumed in an NWP model and temperature forecast errors. Accurate simulation of the direct radiative effect of aerosols on SW radiation is important to the growing solar energy industry because under clear-sky conditions aerosols are the main modulator of SW fluxes (Breitkreuz et al., 2009).

The monthly aerosol climatology described in Tegen et al. (1997) is used in ECMWF's (the European Centre for Medium Range Weather Forecasts) global Integrated Forecast System (IFS) and in the Aire Limitee Adaptation dynamique Developpement InterNational - High Resolution Limited Area Model (ALADIN-HIRLAM) limited area modelling system used in this study. Tompkins et al. (2005) showed that replacing the Tanré at al. (1984) fixed average aerosol distribution in ECMWF's IFS model by the Tegen climatology improved forecasts of the African Easterly Jet. This change in the aerosol climatology also improved the forecast skill and seasonal mean errors (Rodwell and Jung, 2008).

Including a more complete representation of the effects of aerosols in NWP models can improve the meteorological forecasts and is an active area of research (e.g. Mulcahy et al., 2014; Bangert et al., 2012). Using real-time aerosol distributions, rather than climatological data sets, to account for the direct radiative effect of aerosols further improves the quality of the forecasts. Toll et al. (2015b) showed that the accuracy of the forecasts of near-surface conditions by the ALADINHIRLAM system during severe wildfires in summer 2010 in eastern Europe were improved when the direct radiative effect of the realistic aerosol distribution was included in the model hindcasts. Palamarchuk et al. (2016) also found a noticeable sensitivity of the ALADIN-HIRLAM forecasts to the treatment of aerosols where experiments were carried out under aerosol-free conditions, using sea salt aerosols only and using the default aerosols in the model. On the other hand, Toll et al. (2016) showed that when observed aerosol distributions are close to average, improvements in the SW radiation, temperature and humidity forecasts in the lower troposphere are only slightly greater when time-varying realistic aerosol data from the Monitoring Atmospheric Composition and Climate (MACC) reanalysis (Inness et al., 2013) is used in place of the Tegen climatology. Similar conclusions were drawn by Zamora et al. (2005) who showed that, for small AODs, accounting for the climatological average direct radiative effect of aerosols gives very good estimates of SW fluxes, but large biases occur when the AOD is large.

Baklanov et al. (2014), Grell and Baklanov (2011), Zhang (2008) and Vogel et al. (2009) have suggested using coupled air quality and NWP models to improve forecasts of both air quality and weather. However, for operational NWP such coupled models are still too demanding computationally, and this added cost has to be evaluated against improvements in the meteorological forecasts. Mulcahy et al. (2014), Morcrette et al. (2011) and Reale et al. (2011) describe improved forecasts of the radiation budget and near surface conditions in global NWP models when prognostic aerosols are included; however the impact of aerosols on large-scale atmospheric dynamics is generally weak.

The AOD at the wavelength of $550 \mathrm{~nm}$ (AOD550 hereafter) and aerosol inherent optical properties (IOPs: spectral dependence of AOD, single scattering albedo, SSA and asymmetry factor $g$ ) depend on the size, shape and the complex refractive indices of the aerosols and have a significant effect on global downwelling SW (SWD) fluxes. Changes in the IOPs of different aerosols types induced by hygroscopic growth also alter the radiative effect of aerosols (e.g. Cheng et al., 2008; Bian et al., 2009; Markowicz et al., 2003; Zieger et al., 2013). For example, Magi and Hobbs (2003) present measurements of enhanced backscatter by biomass burning aerosols when the relative humidity $(\mathrm{RH})$ is high. Pilinis et al. (1995) estimated that the global radiative forcing due to aerosols doubles for a relative humidity increase from 40 to $80 \%$.

The vertical profile of aerosols is also very important when estimating their direct radiative effect, and there are considerable variations in the vertical distributions of aerosols over Europe (Guibert et al., 2005; Matthias et al., 2004). For example, Huang et al. (2009) showed that vertical profiles of heating rates can vary depending on the vertical profile of dust aerosol. Therefore, inaccuracies result when constant climatological profiles per aerosol species are used (as is the case in ALADIN-HIRLAM which uses the profiles of Tanré et al., 1984). For example, Guibert et al. (2005) analysed the vertical profiles of aerosol extinction over Europe and found that aerosols over southern Europe are concentrated higher in the atmosphere due to the occurrence of dust storm episodes. Meloni et al. (2005) showed that under clear-sky conditions the direct radiative effect of aerosols on surface radiation has a low dependence on the aerosol vertical profile, but that the profile has an impact on the top of the atmosphere forcing, especially for absorbing aerosols. Toll et al. (2015b) evaluated the profile of the aerosol attenuation coefficient for land aerosols in ALADIN-HIRLAM against observations for the summer 2010 Russian wildfires. They found good agreement between the distribution assumed in the model and CALIOP measurements. However, a more general evaluation of the vertical profile of aerosols in the system has not been performed. 
The main goal of the present study is to focus on the impact of AOD550, aerosol IOPs, the vertical distribution of aerosols, relative humidity and radiative transfer algorithms on SW fluxes in diagnostic single-column, clear-sky experiments using the ALADIN-HIRLAM system. Such experiments are useful for developing and testing parameterisations and for running idealised experiments that focus on atmospheric physics in a simplified framework. With these experiments we can evaluate the strengths and weaknesses of the NWP model regarding the treatment of the direct radiative effect of aerosols.

The paper is structured as follows: the model setup and radiation schemes are described in Sect. 2; the aerosol data sets and atmospheric and surface input used in the experiments are given in Sect. 3; descriptions of each of the experiments and sensitivity tests are provided in Sect. 4; the results and discussion are presented in Sect. 5, while conclusions and future work are summarised in Sect. 6.

\section{Model setup}

\subsection{ALADIN-HIRLAM}

The ALADIN-HIRLAM NWP system is used for operational weather forecasting by 26 national meteorological services in Europe and North Africa which form the HIRLAM and ALADIN consortia. Pottier (2016) summarises 42 limited area configurations of the system used by the consortia members. This system can also be used for regional climate simulations (Lindstedt et al., 2015), where the direct radiative effect of aerosols can be of greater importance than in short-range NWP applications.

The HARMONIE-AROME configuration based on Seity et al. (2011) was used in this study. HARMONIE (HIRLAM ALADIN Regional Mesoscale Operational NWP in Europe) denotes the specific configuration of the ALADIN-HIRLAM system maintained by the HIRLAM consortium; AROME is a limited area model developed at Météo-France. The default setup of HARMONIE-AROME for operational NWP uses a $2.5 \mathrm{~km}$ horizontal grid and 65 hybrid model levels with deep convection treated explicitly. This configuration uses ALADIN non-hydrostatic dynamics (Bénard et al., 2010), non-hydrostatic mesoscale (Meso-NH) physics (Mascart and Bougeault, 2011) and the SURFEX externalised surface scheme (Masson et al., 2013). Surface physiographies are prescribed using the $1 \mathrm{~km}$ resolution ECOCLIMAP II database (Faroux et al., 2013) and surface elevation is based on GTOPO30 (USGS, 1998).

We used the single-column version of HARMONIEAROME (also with 65 vertical levels) based on Malardel et al. (2006) for the experiments detailed in this paper. As in Malardel et al. (2006), we will refer to this model configuration as MUSC (Modèle Unifé Simple Colonne). It includes all of the atmospheric and surface parameterisations of HARMONIE-AROME but lacks the large-scale dynamics, horizontal advection, pressure gradient force and largescale vertical motion. Because of the simplifying assumptions, MUSC is not suitable for operational weather forecasting. However, its value lies in the fact that it provides a useful means of studying the sensitivity of the model output to realistic atmospheric conditions and different physical parameterisations. The input to MUSC is derived from the output of a 3-D HARMONIE-AROME experiment. This includes the initial conditions of the atmosphere and surface, surface properties, atmospheric temperatures, specific humidities and wind speeds. Details on the input data used in our experiments are provided in Sect. 3.4.

\subsection{Radiation schemes}

In this study, three shortwave radiation schemes were applied in MUSC: (1) the IFS radiation scheme based on cycle 25R1 (Morcrette, 1991; White, 2004), (2) a new version of the HIRLAM radiation scheme called hlradia (Savijärvi, 1990) containing aerosol parameterisations, and (3) the acraneb2 scheme (Mašek et al., 2016). Table 1 summarises the main characteristics of these radiation schemes.

Each scheme treats the atmosphere as a 1-D column consisting of a set of plane-parallel homogeneous layers. The grid box is split into a cloudy fraction and a clear-sky fraction and does not allow lateral exchanges between them. Atmospheric composition (i.e. aerosols, clouds and atmospheric gases) and the radiative properties of the surface are required as input to the radiation schemes. MUSC was run under clear-sky conditions for the experiments and sensitivity studies presented in this paper. Thus, details on cloud particles and cloud cover are not included. Further information on the basic differences between the radiation schemes is given in the following sub-sections.

\subsubsection{IFS}

The IFS SW radiation scheme (ECMWF, 2004; IFS cycle 25R1) is used by default in MUSC and is the most detailed of the three schemes applied in our experiments. It contains six SW spectral bands (0.185-0.25-0.44-0.691.19-2.38-4.00 $\mu \mathrm{m})$, three in the ultraviolet/visible spectral range and three in the solar infrared range (Mascart and Bougeault, 2011; White, 2004), and 14 LW bands. The IFS clear-sky SW radiative transfer is calculated using the Fouquart and Bonnel (1980) two-stream equations in Mascart and Bougeault (2011) where the reflectance, absorption and transmittance of the atmospheric layers are calculated in a similar manner to that outlined in Coakley and Chylek (1975). These calculations use the IOPs of aerosols and atmospheric molecules. Monthly climatologies of vertically integrated AOD550 for six aerosol categories - continental, sea, urban, desert, volcanic and background stratospheric are used (Tegen et al., 1997). These aerosols are dis- 
Table 1. Summary of aerosol radiation experiments including details of the radiation schemes and aerosol data sets used.

\begin{tabular}{llll}
\hline & IFS & Hlradia & Acraneb2 \\
\hline SW bands & 6 & 1 & 1 \\
\hline LW bands & 14 & 1 & 1 \\
\hline Ozone & Monthly climatology & $\begin{array}{l}\text { Impact of } \mathrm{O}_{3} \text { constant over time } \\
\text { and space }\end{array}$ & Monthly climatology \\
\hline $\begin{array}{l}\text { Radiatively } \\
\text { active gases }\end{array}$ & $\begin{array}{l}\text { Fixed composition mixture of } \\
\mathrm{CO}_{2}, \mathrm{~N}_{2} \mathrm{O}, \mathrm{CH}_{4} \text { and } \mathrm{O}_{2}\end{array}$ & $\begin{array}{l}\text { Impact of } \mathrm{CO}_{2} \text { and } \mathrm{O}_{2} \text { constant } \\
\text { over time and space }\end{array}$ & $\begin{array}{l}\mathrm{Fixed} \mathrm{composition} \mathrm{mixture} \mathrm{of} \\
\mathrm{CO}_{2}, \mathrm{~N}_{2} \mathrm{O}, \mathrm{CH}_{4} \text { and } \mathrm{O}_{2}\end{array}$ \\
\hline $\begin{array}{l}\text { Radiative } \\
\text { transfer }\end{array}$ & $\begin{array}{l}\text { Fouquart and Bonnel }(1980) \\
\text { two-stream equations }\end{array}$ & $\begin{array}{l}\text { Savijärvi (1990) and the } \\
\text { Thomas and Stamnes (2002) } \\
\text { two-stream equations }\end{array}$ & $\begin{array}{l}\text { Ritter and Geleyn }(1992) \text { delta } \\
\text { two-stream system }\end{array}$ \\
\hline
\end{tabular}

tributed among the model levels using Tanré et al. (1984) climatological vertical profiles for each type as described in Sect. 3.1; these profiles are used in the calculations of modellevel fluxes and heating rates. The aerosol IOPs are parameterised following Hess et al. (1998). Monthly climatologies of ozone and a fixed composition mixture of $\mathrm{CO}_{2}, \mathrm{~N}_{2} \mathrm{O}, \mathrm{CH}_{4}$ and $\mathrm{O}_{2}$ are also used. Further details on the aerosols are given in Sect. 3.1.

\subsubsection{HIradia}

Hlradia, the simplest of the three schemes, considers one SW and one LW spectral band. Clear-sky transmittance, reflectance and absorptance of SW flux are taken into account at each model level to obtain the radiative heating (vertical divergence of the net SW flux) and net SW fluxes. The radiative transfer is parameterised rather than solved explicitly, in order to make the scheme very fast for NWP use (Savijärvi, 1990). The impact of ozone, oxygen and carbon dioxide on SW irradiance is assumed to be constant over time and space. In older versions of the scheme, aerosols were accounted for using constant coefficients. However, the scheme has recently been modified to include parameterisations of the direct and semi-direct effects of aerosols, calculated using the two-stream approximation equations for anisotropic non-conservative scattering described by Thomas and Stamnes (2002).

Hlradia uses the GADS/OPAC aerosols of Koepke et al. (1997) and includes the following species: soot, minerals (nucleation, accumulation, coarse and transported modes), sulphuric acid, sea salt (accumulation and coarse modes), water soluble and water insoluble aerosols. The IFS aerosols types described in Sect. 2.2.1 are mapped to GADS/OPAC species in accordance with ECMWF (2004). The aerosol IOPs are averaged over the entire SW spectrum using spectral weightings calculated, using the libRadtran/DISORT software package (Mayer and Kylling, 2005; Stamnes et al., 1988), at a height of $2 \mathrm{~km}$ and a solar zenith angle of $45 \mathrm{de}-$ grees for a standard mid-latitude summer atmosphere (An- derson et al., 1986). These IOPs are referred to as broadband IOPs hereafter in the paper. Hlradia uses the same vertical distributions of aerosols as the IFS scheme.

\subsubsection{Acraneb2}

The acraneb2 scheme (Mašek et al., 2016), which is more complex than hlradia but simpler than IFS, was developed as part of the ALARO-1 suite of physics parameterisations. Similar to hlradia, it is a broadband scheme using a single SW radiation interval. However, it uses the Ritter and Geleyn (1992) delta two-stream system for the clear-sky radiative transfer calculations with coefficients computed according to Räisänen (2002) i.e. by averaging the coefficients of all of the radiatively active species, weighted by their optical thicknesses. Acraneb2 uses the same climatologies of ozone and fixed composition mixture of $\mathrm{CO}_{2}, \mathrm{~N}_{2} \mathrm{O}, \mathrm{CH}_{4}$ and $\mathrm{O}_{2}$ as IFS. It also uses the same aerosol climatology as IFS but where the IOPs are spectrally averaged over the six IFS bands as is done for hlradia. One of the strengths of acraneb2 is that it possesses selective intermittency where slowly varying gaseous transmissions are updated on a timescale of hours (using a simple correction for the actual sun elevation).

\section{Input and validation data}

\subsection{Aerosol climatology}

The direct SW radiative effect of aerosols in MUSC is calculated using vertically integrated AOD550 and the following aerosol IOPs: AOD spectral scaling coefficients, spectral SSA and $g$. The spectral scaling coefficients are particularly important in the wildfire case study experiments because of the high dependence of the AOD of biomass burning aerosols on wavelength. The indirect radiative effect of aerosols is not included in the current version of the ALADIN-HIRLAM NWP system.

Monthly climatologies of Tegen et al. (1997) vertically integrated AOD550 for six aerosol categories (see Sect. 2.2.1) 
are used by default in MUSC. The aerosol IOPs for each spectral band and aerosol type are parameterised following Hess et al. (1998). The default aerosol types in MUSC are translated to GADS aerosol species before being used by hlradia as outlined in Sect. 2.2.2. Spectrally averaged IOPs are used in both hlradia and acraneb2 as outlined in Sect. 2.2.2 and 2.2.3.

Each radiation scheme uses Tanré et al. (1984) climatological vertical profiles to distribute the AODs on model levels for each aerosol type. In these schemes the surfacenormalized vertical distribution of AOD, $\alpha(z)$, is described using the following exponential form which results in a decrease in aerosol attenuation with height

$\alpha(z)=\exp (-z / h)$,

where $z$ is the height above the ground and $h$ is a vertical scale height.

It is also possible to replace the monthly Tegen climatology available in MUSC with other data sets such as the MaxPlanck-Institute Aerosol Climatology version 1 (MACv1, Kinne et al., 2013) or the MACC reanalysis (Inness et al., 2013) data set, which includes assimilated AOD measurements. For comparison, the MACC and Tegen aerosol data sets for August 2010 are shown in Fig. 1 (see Sect. 5.1 for further details).

\subsection{Aerosol observations}

In the Russian wildfire case study (see Sect. 4.1 for details) we ran some of the simulations using AOD and IOPs derived from CIMEL sun/sky radiometer measurements recorded at the Aerosol Robotic Network (AERONET, Holben et al., 1998) station in Tõravere $\left(58.3^{\circ} \mathrm{N} ; 26.5^{\circ} \mathrm{E}\right)$, Estonia. Quality-controlled level 2 AERONET data (Smirnov et al., 2000) were used. The AOD was derived (by AERONET) from measurements of the direct SW radiation flux at various wavelengths (Holben et al., 1998). SSA and $g$ were calculated from diffuse irradiance measurements using an inversion algorithm by Dubovik and King (2000).

AOD550 and AOD scaling coefficients for the six IFS SW bands, assumed valid for the land (soot) aerosol type, were derived from the spectral AERONET measurements. These measurements range from 340 to $1020 \mathrm{~nm}$ whereas the IFS radiation scheme includes SW wavelengths from 185 to $4000 \mathrm{~nm}$ in the SW. Therefore, aerosol inputs for the first and sixth SW bands in the IFS scheme (1.19-2.38 and 2.38$4.00 \mu \mathrm{m})$ were extrapolated from the AERONET measurements. This may result in an error in these bands but the majority of the SW flux is contained in the remaining bands. As in the case of climatological aerosols, spectral averages of the IOPs are derived for use in the hlradia and acraneb2 schemes.

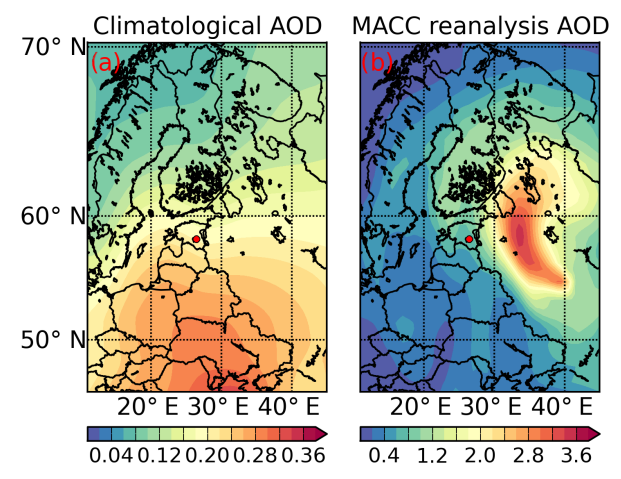

Figure 1. (a) AOD550 for August in the default climatology in the ALADIN-HIRLAM NWP system (Tegen et al., 1997). (b) AOD for 8 August 2010 from the MACC reanalysis (Inness et al., 2013). The location of Tõravere $\left(58.3^{\circ} \mathrm{N}, 26.5^{\circ} \mathrm{E}\right)$, for which the MUSC single-column experiments are run, is shown as a red dot in both panels. Note the factor of 10 difference in AOD between the Tegen climatology and the MACC reanalysis.

\subsection{BSRN radiative flux measurements}

Global SWD radiation measurements recorded at Tõravere were compared to simulated fluxes for the August 2010 wildfire case study (see Sect. 4.1). These measurements are independent of the AERONET network but are part of the Baseline Surface Radiation Network (BSRN, Kallis, 2010) measurements described by Ohmura et al. (1998).

\subsection{Atmospheric and surface input for MUSC}

The input atmospheric and surface fields for the severe wildfire experiments at Tõravere were generated from hourly output snapshots from a 3-D HARMONIE-AROME simulation. The simulation was carried out on a $2.5 \mathrm{~km}$ grid with 65 vertical levels over Estonia for 8 August 2010 as described in Toll et al. (2015a) and the outputs were interpolated to the geographical coordinates of Torravere for use by MUSC. As the experiments in this paper were run assuming clear-sky conditions, model-level cloud water and cloud ice values were manually removed from each of the hourly atmospheric profile files generated for MUSC. These values were small but needed to be removed to allow direct comparison with observations because cloud cover observations recorded at the Torravere synoptic station showed that the sky was clear until 14:00 UTC.

\section{Experiments}

Three sets of experiments were conducted in this study (short names for each experiment have been included in brackets): (1) a case study of the summer 2010 Russian wildfires where smoke plumes affected Estonia (WFEXP) and the global SWD irradiance from MUSC was compared to obser- 
Table 2. Summary of aerosol radiation experiments including details of the radiation schemes and aerosol data sets used.

\begin{tabular}{|c|c|c|c|}
\hline Experiment & $\mathrm{SW}$ radiation scheme & AOD550 & $\begin{array}{l}\text { Other IOPs (AOD scaling, } \\
\text { SSA, } g \text { ) }\end{array}$ \\
\hline \multirow[t]{3}{*}{$\begin{array}{l}\text { Russian wildfire } \\
\text { experiments: WFEXP }\end{array}$} & IFS & $\begin{array}{l}\text { Aerosol-free } \\
\text { Tegen climatology } \\
\text { Observed } \\
\text { Observed }\end{array}$ & $\begin{array}{l}\text { Aerosol-free } \\
\text { Hess parameterisation } \\
\text { Hess parameterisation } \\
\text { Observed }\end{array}$ \\
\hline & hlradia & $\begin{array}{l}\text { Aerosol-free } \\
\text { Tegen climatology } \\
\text { Observed } \\
\text { Observed }\end{array}$ & $\begin{array}{l}\text { Aerosol-free } \\
\text { Hess parameterisation } \\
\text { Hess parameterisation } \\
\text { Observed }\end{array}$ \\
\hline & acraneb2 & $\begin{array}{l}\text { Aerosol-free } \\
\text { Tegen climatology } \\
\text { Observed } \\
\text { Observed }\end{array}$ & $\begin{array}{l}\text { Aerosol-free } \\
\text { Hess parameterisation } \\
\text { Hess parameterisation } \\
\text { Observed }\end{array}$ \\
\hline \multirow[t]{3}{*}{$\begin{array}{l}\text { AOD550 experiments: } \\
\text { AODEXP }\end{array}$} & IFS & Range $[0,5]$ in steps of 0.1 & $\begin{array}{l}\text { Hess parameterisation } \\
\text { Observed }\end{array}$ \\
\hline & hlradia & Range $[0,5]$ in steps of 0.1 & $\begin{array}{l}\text { Hess parameterisation } \\
\text { Observed }\end{array}$ \\
\hline & acraneb2 & Range $[0,5]$ in steps of 0.1 & $\begin{array}{l}\text { Hess parameterisation } \\
\text { Observed }\end{array}$ \\
\hline $\begin{array}{l}\text { Vertical profile of aerosols } \\
\text { experiments: VPEXP }\end{array}$ & IFS & Observed (10:00 UTC) & Observed (10:00 UTC) \\
\hline \multirow[t]{2}{*}{$\begin{array}{l}\text { Relative humidity } \\
\text { experiments: RHEXP }\end{array}$} & hlradia & $\begin{array}{l}0.1 \\
1.0\end{array}$ & $\begin{array}{l}\text { Hess parameterisation } \\
\text { Hess parameterisation }\end{array}$ \\
\hline & IFS & $\begin{array}{l}0.1 \\
1.0\end{array}$ & $\begin{array}{l}\text { Hess parameterisation } \\
\text { Hess parameterisation }\end{array}$ \\
\hline \multirow{4}{*}{$\begin{array}{l}\text { Radiative transfer } \\
\text { experiments: RTEXP }\end{array}$} & IFS & Total AOD $($ not $550 \mathrm{~nm})$ in the range $[0.01,5]$ & $\mathrm{SSA}=0.95, g=0.7$ \\
\hline & hlradia & Total AOD in the range $[0.01,5]$ & $\mathrm{SSA}=0.95, g=0.7$ \\
\hline & acraneb2 & Total AOD in the range $[0.01,5]$ & $\mathrm{SSA}=0.95, g=0.7$ \\
\hline & DISORT & Total AOD in the range $[0.01,5]$ & $\mathrm{SSA}=0.95, g=0.7$ \\
\hline
\end{tabular}

vations, (2) the sensitivity of SWD fluxes to AOD (AODEXP), the aerosol vertical profile (VPEXP) and relative humidity (RHEXP) and (3) aerosol radiative transfer (transmittances) compared to the accurate DISORT scheme (RTEXP). (2) and (3) are sensitivity experiments and do not simulate the summer 2010 wildfires. A summary of these experiments in terms of the aerosols and radiation schemes used is given in Table 2 .

\subsection{Russian wildfire case study (WFEXP)}

One of the worst cases of atmospheric pollution over Estonia in recent decades (Witte et al., 2011; Huijnen et al., 2012) occurred on 8 August 2010 when forest fires in the Baltic region coincided with severe thunderstorms (Toll and Männik, 2015). To study this extreme pollution event, we focussed MUSC single-column experiments on the Tõra- vere location in Estonia. This location was selected for three reasons: (1) the smoke plume had a strong impact on the area, (2) measurements of aerosol IOPs were available from a local AERONET station and (3) radiation flux measurements were available from the BSRN archive. We ran a series of 12 experiments using MUSC; 4 aerosol scenarios for each of the 3 radiation schemes (see Table 2 for summary). In particular, the following aerosol treatments were considered: (1) aerosol-free, (2) climatological AOD550 and parameterised IOPs, (3) observed AOD550 and parameterised IOPs and (4) aerosol observations (AOD550 and IOPs). In the experiments using observations (either AOD550 or both AOD550 and IOPs) the aerosols were assigned to the land/continental aerosol category while the remaining five categories of IFS aerosols (see Sect. 2.2.1) were set to zero. 
Accordingly, the climatological vertical distribution of IFS land aerosols was assumed.

In each experiment, a single time step diagnostic MUSC simulation was run using the relevant input file (see Sect. 3.4) as the starting point and repeated for each hour between 00:00 and 24:00 UTC. Thus, a series of single time step simulations were run starting from the 00:00 UTC input file, 01:00 UTC input file and so on up to 24:00 UTC. The model was run in diagnostic mode in order to focus on the radiative properties when the state of the atmosphere and surface had not yet evolved from the initial values.

\subsection{Aerosol sensitivity experiments (AODEXP, RHEXP and VPEXP)}

In the aerosol sensitivity experiments outlined below, the 10:00 UTC atmospheric and surface files generated for the wildfire case study were used as input. In each of the experiments the relative effect of a different aerosol characteristic (AOD550, relative humidity and the vertical distribution of aerosols) on SWD fluxes was investigated. In each case, single time step diagnostic MUSC simulations were conducted for a range of values of each aerosol characteristic (see Table 2 for the summary).

Six experiments were carried out to investigate the effect of AOD550 on SWD fluxes (AODEXP). In particular, two aerosol IOP configurations (observed and parameterised) were used with the IFS, hlradia and acraneb2 radiation schemes. In each case we varied AOD550 from 0 (no aerosols) to 5 (extremely polluted) in steps of 0.1 to investigate its influence on SW radiation fluxes at the surface.

The aerosol radiative transfer algorithms in the IFS and acraneb2 radiation schemes in the current version of the ALADIN-HIRLAM system assume a constant RH of $80 \%$. In this regard, the hlradia scheme is more advanced as the RH dependence has been incorporated into the calculation of the radiative effect of aerosol IOPs. Four RH experiments (RHEXP) were carried out: two using hlradia and two using IFS where the latter were used to normalise the results from hlradia. As in AODEXP, the 10:00 UTC atmospheric and surface input files were used for the RHEXP experiments. Parameterised aerosol IOPs were employed in each case. Using hlradia, a series of single time step diagnostic MUSC experiments were run for $\mathrm{RH}$ in the range $0-1.0$ in increments of 0.1 . The input atmospheric file was not edited to achieve the required RH. Instead, we hard-coded RH only for the aerosol transmission calculations. The series of RH simulations were run for AOD550 values of 0.1 and 1.0, which covers average and extreme aerosol quantities. Using IFS, it was only necessary to run one diagnostic MUSC simulation for each AOD550 because the IFS aerosol calculations were formulated using an assumed $\mathrm{RH}$ of $80 \%$.

In the VPEXP experiments we tested the sensitivity of SWD fluxes and the SW heating rate to the vertical scale height $h$ (see Sect. 3.1) using MUSC with the IFS radi- ation scheme. The experiments were initialised using the 10:00 UTC input files from the wildfire experiment and observed AOD550 and IOPs assigned to the land aerosol category. In MUSC, $h$ has a default value of $1000 \mathrm{~m}$ for land aerosols. We ran single time step diagnostic experiments using the following values of $h$ for land aerosols: 527, 1000 (default), 2109 and $8343 \mathrm{~m}$ (experiments were also run using other values of $h$ but the four values included here capture the range of sensitivity of the SWD fluxes and SW heating rate). For smaller $h$, the aerosols are concentrated closer to the ground while larger values of $h$ spread the aerosols higher into the atmosphere. The acraneb2 and hlradia schemes use the same vertical distribution of aerosols as IFS and exhibit a similar sensitivity in terms of SWD fluxes and the SW heating rate (results not included).

\subsection{Aerosol radiative transfer (RTEXP)}

Accurate aerosol radiative transfer is of equal importance to accurate aerosol IOPs. To examine the performance of the aerosol radiative transfer algorithms in MUSC, we extracted the relevant subroutines from the IFS, hlradia and acraneb2 radiation scheme codes and ran these as stand-alone formulations. These calculations require optical thickness, SSA, $g$ and the cosine of the solar zenith angle as input.

We ran experiments using the IFS Fouquart and Bonnel (1980) clear-sky formulation, the two-stream approximation (Thomas and Stamnes, 2002) used in hlradia and the acraneb2 Ritter and Geleyn (1992) two-stream approximation to calculate SW transmission through a homogeneous atmospheric layer with optical properties resembling those of aerosols. In particular, we used SSA $=0.95, g=0.7$ and cosine of the solar zenith angle of 0.6 while varying the optical depth between 0.1 and 5. Additionally, we used the accurate DISORT radiative transfer scheme (Stamnes et al., 1988) with 30 streams and the same input as the IFS, hlradia and acraneb2 radiative transfer calculations.

\section{Results and discussion}

\subsection{Russian wildfire case study (WFEXP)}

The results presented in this section include a comparison of AOD550 for the Tegen and MACC reanalysis climatologies, time series of spectral AOD, SSA and $g$ from AERONET and experiments run using MUSC with observed and climatological aerosol data and the IFS, hlradia and acraneb2 radiation schemes. Figure 1 shows the AOD550 over northwestern Europe on 8 August 2010 for the Tegen climatology used in MUSC and the MACC reanalysis data set (Inness et al., 2013). It is clear that the Tegen climatology greatly underestimates aerosols when pollution is heavy, as was the case over Estonia and eastern Russia on 8 August 2010. Overall, over northwestern Europe, the values of the realistic MACC AOD550 (maximum 3.5) are an order of magnitude higher 


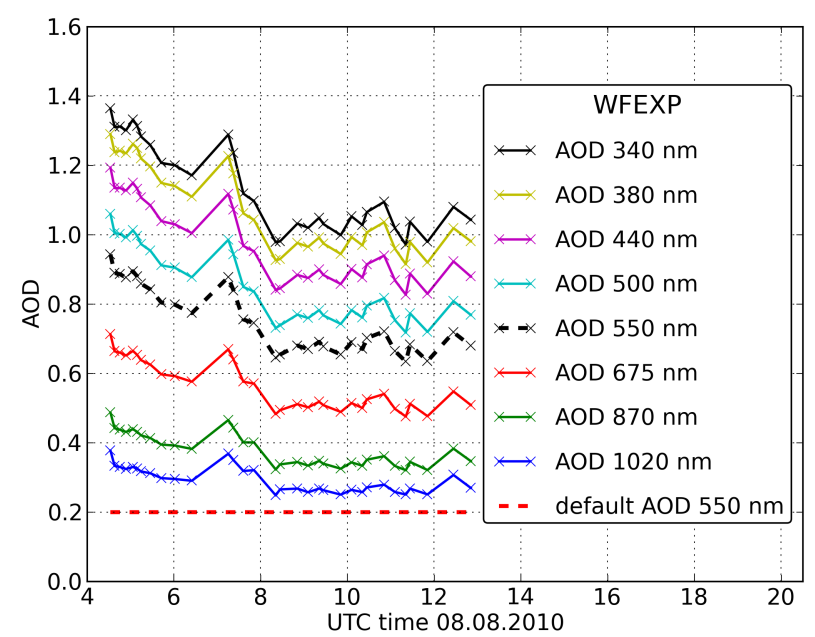

Figure 2. AERONET measurements of AOD at Tõravere on $8 \mathrm{Au}$ gust 2010 for seven SW wavelengths (nm). The AOD550 derived from these measurements (black dashed line) and the default climatological AOD550 at Tõravere (red dashed line) are also shown in the figure. Data are not available after 14:00 UTC due to the presence of clouds.

than in the Tegen climatology (maximum 0.33) for August which highlights a drawback of using the Tegen data set.

Figure 2 shows a time series of AOD at Torravere on 8 August 2010 for seven wavelengths (measurements from the AERONET archive). The strong spectral dependence of AOD is clear from the figure; AOD is higher for shorter wavelengths. This notable wavelength dependence is characteristic of biomass burning aerosols (Slutsker and Kinne, 1999). The AOD550, also shown in Fig. 2 (black dashed line), used in the experiments involving observations rather than the Tegen climatology, was calculated using the AERONET AOD at $500 \mathrm{~nm}$ (cyan line) and the Ångström exponent in the 440-675 nm spectral interval. For comparison, the significantly lower AOD550 from the Tegen climatology (red dashed line) is also included in the figure.

The remaining aerosol IOPs, SSA and $g$, from the AERONET inversion products database are shown in Fig. 3 (continuous curves) where daily averages are plotted as a function of wavelength. Although daily averages are shown, the time dependence of SSA and $g$ on 8 August was small. The asymmetry factor, $g$, varies from 0.56 to 0.7 across the wavelength range and has an average value of 0.634 . The latter was used in the wildfire experiments run using hlradia or acraneb2 with aerosol observations. The spectral values of $g$ were interpolated to the six SW bands of IFS for experiments using this scheme.

The aerosol scattering per extinction ratio, represented by SSA, is high (close to 0.96 with a spectral average of 0.955) at each wavelength with little SW spectral dependence (Fig. 3, red continuous curve). This is similar to results by Dubovik et al. (2002) who showed that the typical SSA

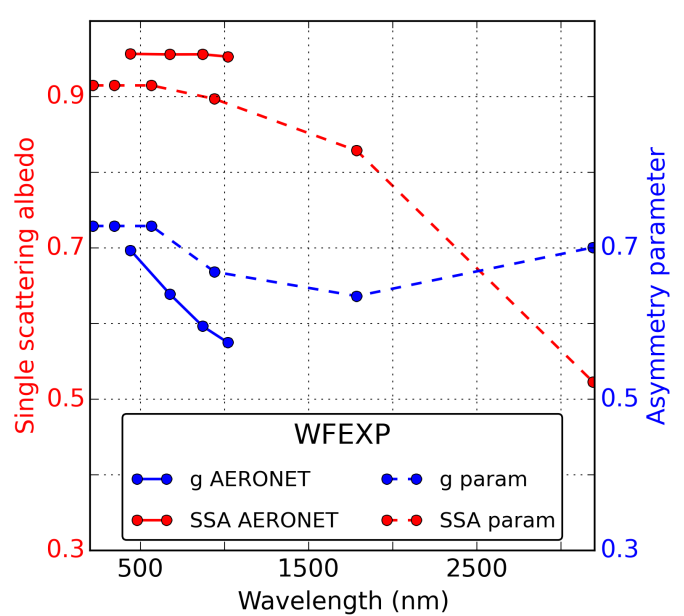

Figure 3. Single scattering albedo (SSA, red continuous) and asymmetry factor ( $g$, blue continuous) at Tõravere on 8 August 2010, as a function of wavelength, attained from the AERONET inversion products database. The data are averaged over the day - data at three different times were available and the time dependence was small. The parameterised SSA and $g$ for the six IFS SW bands (points are plotted at the midpoint between each of the bands) are depicted by the dashed lines. Both observed and parameterised SSA and $g$ values are spectrally averaged for use by the hlradia and acraneb2 radiation schemes.

of smoke from biomass burning in Boreal forests is high. However, the scattering of smoke particles from this Russian wildfire event was higher than that of plumes from typical biomass burning in Boreal forests (Chubarova et al., 2012). As in the case of $g$, the average SSA was used in the hlradia and acraneb2 wildfire experiments involving aerosol observations while the spectral SSAs were interpolated to the IFS SW bands before use in the corresponding IFS experiments. The Hess et al. (1998) parameterised values of SSA and $g$ for the six IFS SW bands in MUSC are also shown in Fig. 3 (dashed lines). As in the case of SSA and $g$ based on observations, the parameterised values are spectrally averaged for use by hlradia and acraneb2.

Figure 4a shows the global SWD radiative flux at the Earth's surface simulated using MUSC with the IFS radiation scheme for 8 August 2010 at Tõravere. We ran an experiment for each of the following four aerosol scenarios (also summarised in Table 2): (1) aerosol-free (red curve), (2) climatological AOD550 and parameterised IOPs (black curve), (3) observed AOD550 and parameterised IOPs (green curve) and (4) observed AOD550 and IOPs (cyan curve) and compared the global SWD fluxes to BSRN observations (blue curve). The discrepancy between simulated and observed SWD irradiance after 14:00 UTC is due to the development of convective clouds (Toll et al., 2015a) which are not accounted for in the MUSC clear-sky simulations.

The biases in global SWD flux (relative to observations) for the experiments using each radiation scheme (and not 
(a)

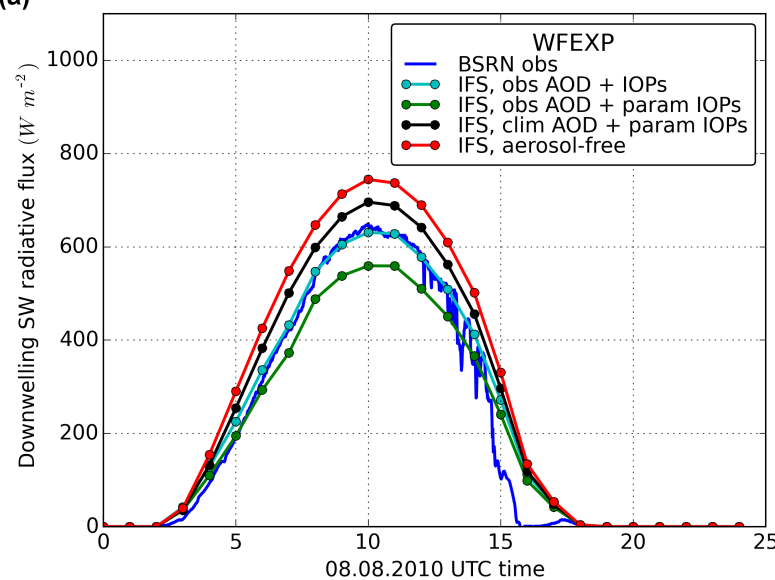

(b)

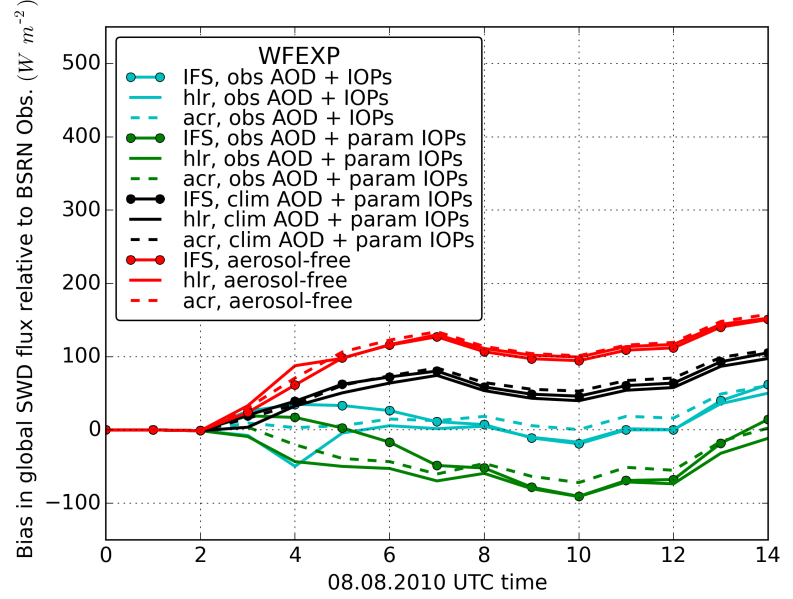

Figure 4. (a) Time series of global SWD radiation flux $\left(\mathrm{W} \mathrm{m}^{-2}\right)$ at Tõravere on 8 August 2010 simulated using MUSC (with the IFS radiation scheme) for four aerosol scenarios (red: aerosol free; black: climatological AOD550 and parameterised IOPs; green: observed AOD550 and parameterised IOPs; cyan: observed AOD550 and IOPs). BSRN global SWD flux measurements are shown in blue. (b) Time series of the bias in global SWD flux relative to BSRN observations for the same four aerosol scenarios as in panel (a). The results when the IFS radiation scheme was used are depicted by a dotted continuous line; the hlradia (hlr) and acraneb2 (acr) biases are shown using continuous and dashed lines, respectively. Only data up to 14:00 UTC are shown because clouds developed after that, which were not included in the MUSC simulations.

just IFS) and the four different aerosol scenarios are depicted in Fig. 4b (IFS dotted continuous lines, hlradia continuous lines, acraneb 2 dashed lines; the aerosol scenario colour scheme is the same as in Fig. 4a). Overall, the results for the three schemes are similar (mostly to within $10-20 \mathrm{~W} \mathrm{~m}^{-2}$ of each other for global SWD irradiance which can be seen by comparing each group of three curves of the same colour), particularly in their response to the different aerosol scenarios. The largest discrepancies occur in the early morning; in hlradia this occurs because the sphericity of the atmosphere is not taken into account. The early morning discrepancies in SWD for the IFS scheme are thought to be due to the delta two-stream formulation but further work is required on this topic. When the direct radiative effect of aerosols was excluded, global SWD fluxes were overestimated by $\sim 120 \mathrm{~W} \mathrm{~m}^{-2}$ or $19 \%$ (red curves) at midday compared to BSRN observations. Accounting for the climatological average effect of aerosols using the Tegen et al. (1997) data set and Hess et al. (1998) IOP parameterisations (black curves) improves the simulation of global SWD flux compared to the aerosol-free simulation. However, there is still an overestimation of $60 \mathrm{~W} \mathrm{~m}^{-2}$ or $10 \%$ at noon, because the observed AOD is higher than the climatological average (see Figs. 1 and 2).

The use of AOD550 and IOPs derived from AERONET observations gives very good agreement between the modelled and observed global SWD fluxes for each of the three radiation schemes (cyan curves, bias $<20 \mathrm{~W} \mathrm{~m}^{-2}$ or $4 \%$ at noon). SWD flux was underestimated by $\sim 70 \mathrm{~W} \mathrm{~m}^{-2}$ or $11 \%$ (green curves) at noon when the direct radiative effect of aerosols was accounted for using the observed AOD550 combined with parameterised SSA, $g$ and spectral scaling factors of land aerosols. This underestimation can be explained by two factors.

Firstly, using the climatological AOD scaling factors for Tõravere in August leads to AOD values which are $60 \%$ higher than those estimated from the AERONET spectral measurements. Secondly, using a delta-Eddington optical depth scaling factor $\left(1-\mathrm{SSA}^{2}\right.$; Joseph et al., 1976) based on the climatological SSA and $g$ values causes this factor to be approximately $7 \%$ lower than the corresponding scaling factor based on the observed SSA and $g$ values. The combination of these two factors results in a scaled SW AOD of land aerosols that is $48 \%$ larger than the observation-based value.

\subsection{Aerosol sensitivity tests}

\subsubsection{AOD (AODEXP)}

The sensitivity of global SWD fluxes to AOD550 is shown in Fig. 5a for MUSC experiments run using the IFS, hlradia and acraneb 2 radiation schemes. The results depicted by the cyan curves are for the case where observed IOPs (i.e. 10:00 UTC observation at Tõravere from the AERONET archive) were used in the simulations. Parameterised IOPs were used where the experiment results are shown in green. For an AOD550 of 1 , global SWD irradiance is $\sim 100 \mathrm{~W} \mathrm{~m}^{-2}$ lower when parameterised rather than observed IOPs were used, regardless of the radiation scheme. The reason for this difference has been discussed in Sect. 5.1.

The effect of AOD550 on direct SWD flux is shown in Fig. $5 \mathrm{~b}$ for the three radiation schemes and observed (cyan curves) and parameterised (green curves) IOPs. For example, when parameterised IOPs were used, an increase in 


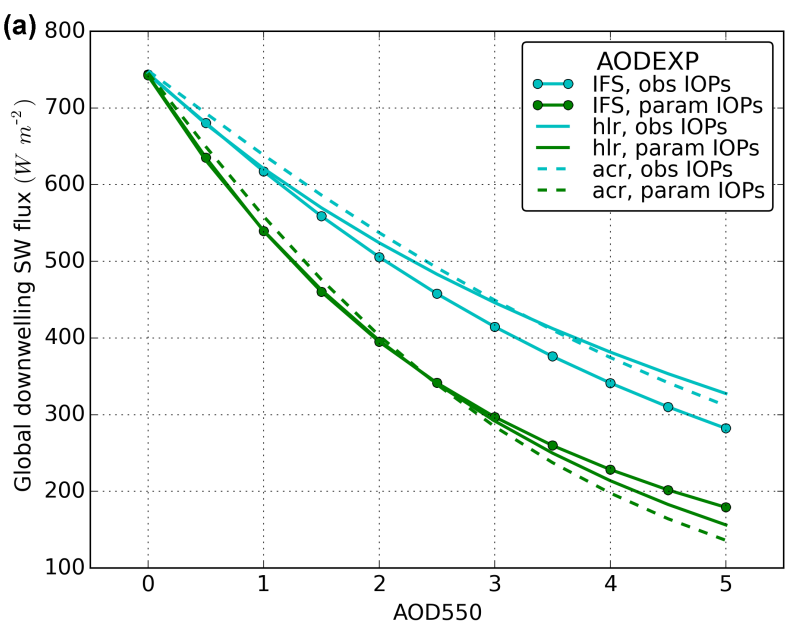

(b)

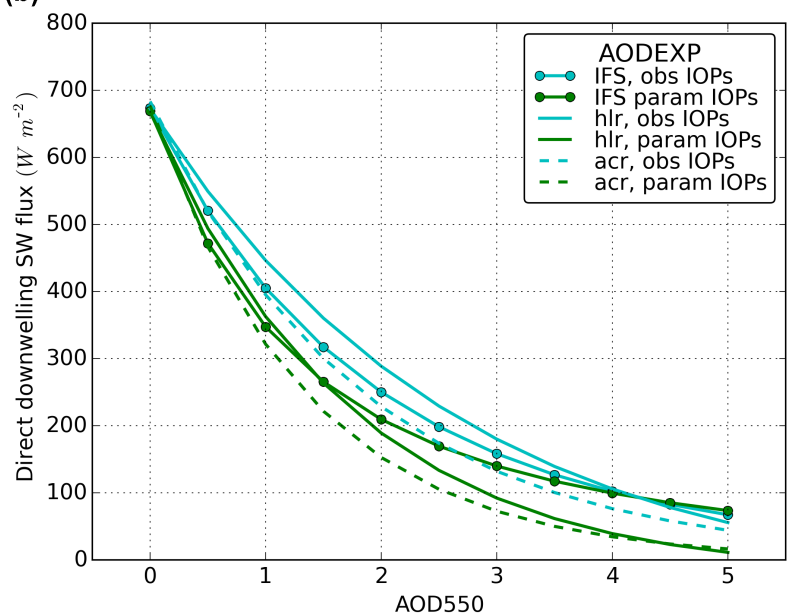

Figure 5. Global SWD flux as a function of AOD550 for MUSC experiments run using the IFS (dotted continuous curve), hlradia (continuous curve) and acraneb2 (dashed curve) radiation schemes. The results depicted by the cyan curves are for the cases where observed IOPs (SSA, $g$ and AOD scaling) were used. Parameterised IOPs were used for those shown in green. The direct SWD flux for MUSC experiments using the same aerosol scenarios and radiation schemes as in panel (a) is shown in panel (b).

AOD550 from 0 to 1 (i.e. no aerosols to heavy pollution) reduced the global SWD irradiance by $\sim 200 \mathrm{~W} \mathrm{~m}^{-2}$ or $27 \%$ (Fig. 5a) but had a greater effect on the direct SWD flux $\left(\sim 330 \mathrm{~W} \mathrm{~m}^{-2}\right.$ or $49 \%$, Fig. $\left.5 b\right)$. Direct SWD flux is very sensitive to AOD because it is extinguished by both absorption and scattering. Due to forward scattering, the global SWD flux is less affected because the forward scattered irradiance reaches the surface as diffuse SWD irradiance (i.e. some of the direct beam extinguished by scattering reaches the surface as diffuse irradiance, resulting in an increase in diffuse flux). The influence of AOD550 on global SWD flux is similar for each radiation scheme. Global SWD fluxes are lower when the parameterised IOPs are used; this is because
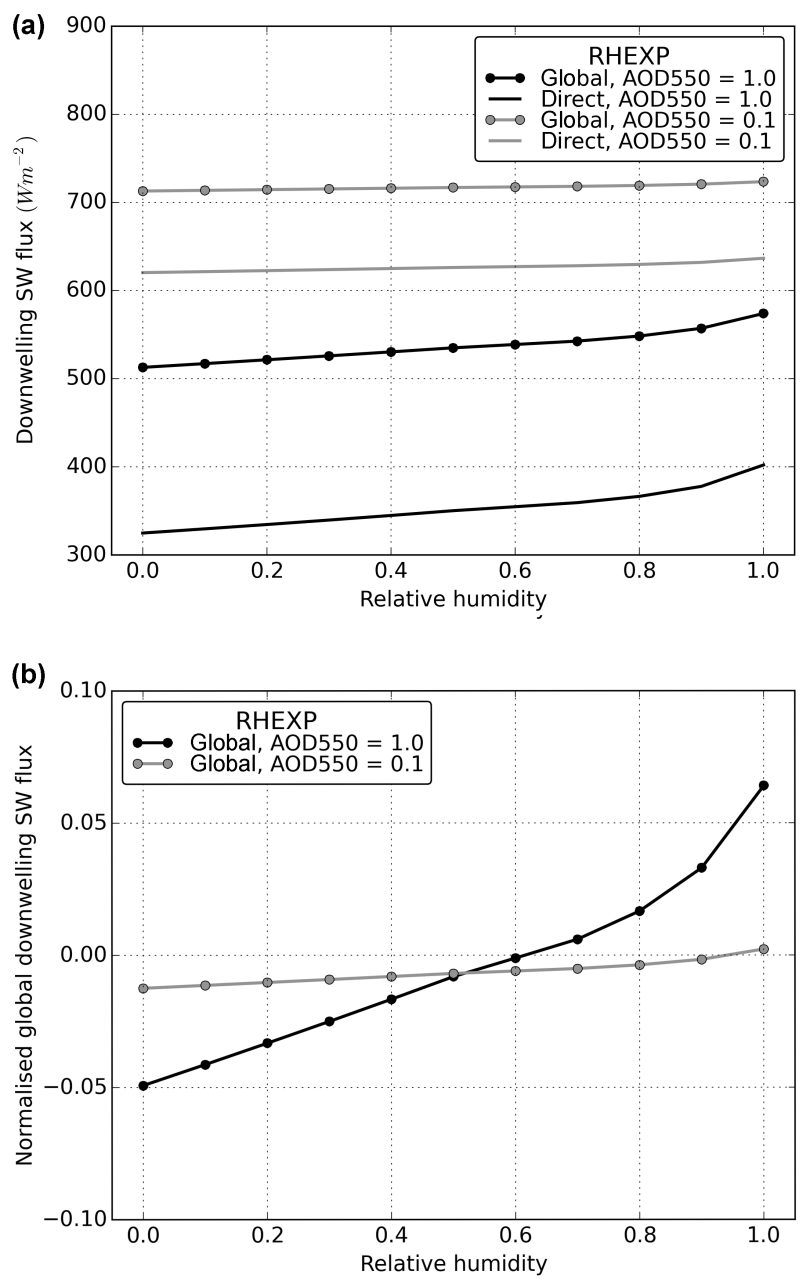

Figure 6. (a) Global (dotted continuous curves) and direct (continuous curves) SWD fluxes, as a function of relative humidity, simulated using MUSC with the hlradia radiation scheme for AOD550 values of 0.1 (grey) and 1.0 (black). (b) Similar to panel (a) but shows global SWD flux normalised relative to a corresponding experiment run using the IFS radiation scheme. The IFS scheme assumes a RH of $80 \%$ for land aerosols.

of the combination of a higher AOD scaling factor and lower delta-Eddington optical depth scaling factor than based on observations as discussed in Sect. 5.1. This sensitivity test clearly illustrates the large effect AOD550 and the IOPs have on SW radiative fluxes at the surface and emphasises the importance of using the correct aerosol IOPs in NWP.

\subsubsection{Relative humidity (RHEXP)}

The impact of relative humidity (RH), accounted for in the aerosol radiative transfer calculations in the hlradia scheme, on global and direct SWD fluxes is shown in Fig. 6a. RH was varied from 0 to 1 in steps of 0.1 ; the AOD550 was set to 0.1 in the grey curves and to 1.0 (significant pollution) in the black curves. IFS land aerosol parameterised IOPs at 
Tõravere were used. Increasing RH from 0 to 1 increases global SWD flux by $1.5 \%$ when AOD550 $=0.1$ (grey line with filled circles) and by $12 \%$ when AOD550 $=1.0$ (black line with filled circles). The effect on the corresponding direct SWD fluxes is greater as expected (increases of 2.5 and $24 \%$ for AOD550 $=0.1$ and 1.0 , respectively, grey and black continuous lines). Figure 6b shows global SWD irradiance from the experiments run using hlradia, an AOD550 of 0.1 (grey) and 1.0 (black) and RH varying from 0 to 1.0 as before. In this case, the global SWD fluxes are normalised using output from a corresponding experiment run using the IFS radiation scheme. In the IFS scheme, a constant RH of $80 \%$ is assumed for "land" aerosols. For AODs close to the climatological value (i.e. 0.1 here) the relative differences between global SWD fluxes for experiments using hlradia and IFS are small and negligible at a RH of 0.8 . As the humidity deviates from 0.8 , particularly for larger AODs, the differences between the global SWD fluxes from experiments using hlradia and IFS grow to $\pm 6 \%$. When the AODs are close to the climatological average (of the order of 0.1), the influence of RH on aerosol radiative transfer is less than $1 \%$. In such cases, the assumption of a constant RH by the IFS and acraneb2 schemes is acceptable and is not a major source of error. On the other hand, for cases where pollution is high, the influence of RH on global SWD flux is $\sim \pm 6 \%$ and could be important, particularly for solar energy applications.

\subsubsection{Vertical distribution of aerosols (VPEXP)}

The inherent uncertainties associated with assuming fixed vertical profiles were investigated by modifying the assumptions about the shape of the IFS climatological vertical aerosol profile. Figure 7a shows normalised net SW fluxes on pressure levels for MUSC experiments run with the IFS radiation scheme and vertical scale heights $(h$, of land aerosols) of $527 \mathrm{~m}$ (red), $1000 \mathrm{~m}$ (default, green), $2109 \mathrm{~m}$ (cyan) and $8343 \mathrm{~m}$ (blue). AERONET aerosol observations at 10:00 UTC over Tõravere were used as input. The net SW flux is normalised relative to the aerosol-free case and varies by no more than $4 \%$ at each pressure level for the range of $h$ plotted. For example, at $1000 \mathrm{hPa}$ the net $\mathrm{SW}$ flux varies by less than $3 \%$ with $h$, and by less than $4 \%$ at $800 \mathrm{hPa}$.

Figure $7 \mathrm{~b}$ shows the $\mathrm{SW}$ heating rates for the same experimental setup as in Fig. 7a, where the heating rate is normalised relative to the corresponding aerosol-free simulations. The heating rates in the boundary layer changed by up to a factor of 2 in response to the aerosol vertical distribution (e.g. when $h$ is halved (red curve) compared to the default (green curve) the SW heating rate approximately doubles). Figure $7 \mathrm{~b}$ also clearly illustrates that large values of $h$ spread the aerosol higher in the atmosphere (blue curve) while for smaller values, the aerosols are concentrated closer to the ground (red curve).
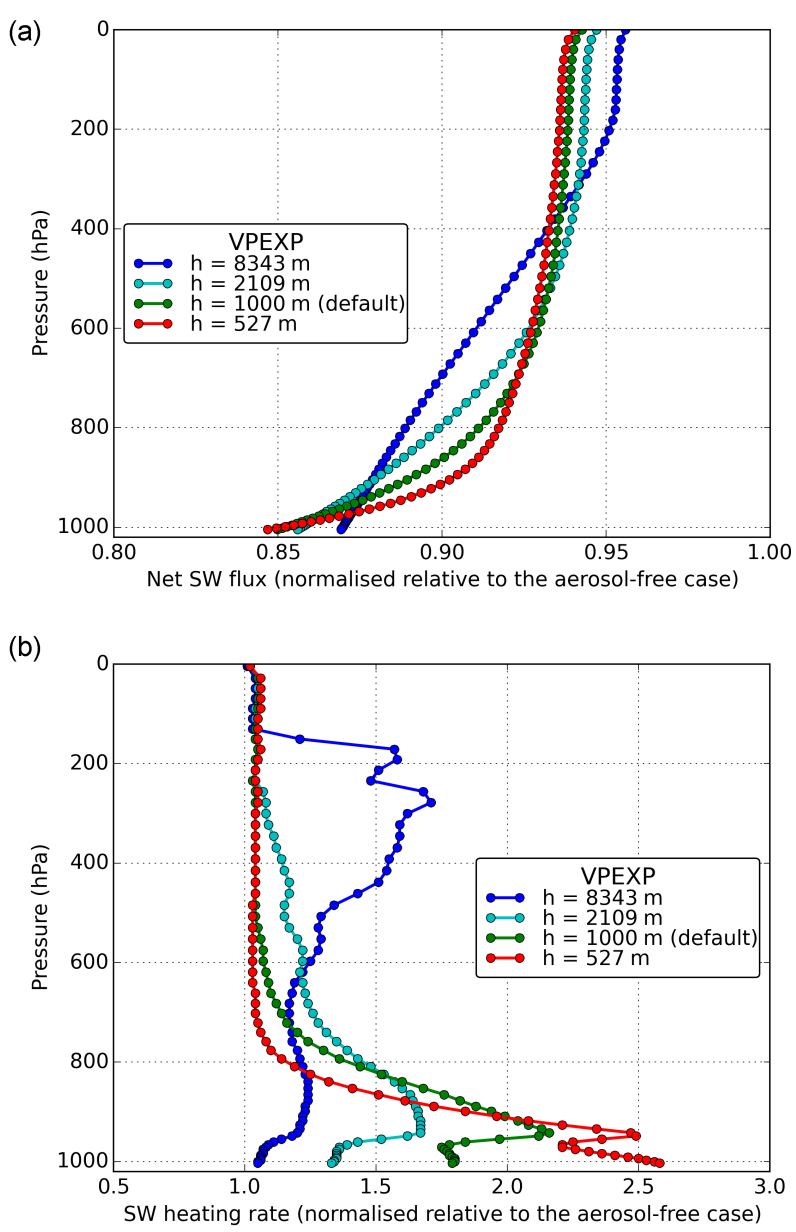

Figure 7. (a) Net SW radiation fluxes (normalised relative to the aerosol-free case) as a function of atmospheric pressure for four vertical scale heights $(h)$ of IFS land aerosols. (b) Similar to panel (a) but shows the normalised SW heating rate. The experiments were carried out using the IFS radiation scheme.

\subsection{Aerosol radiative transfer (RTEXP)}

Figure 8a shows transmission as a function of optical depth through a homogeneous atmospheric layer containing aerosol (SSA $=0.95, g=0.7$, cosine of the solar zenith angle set to 0.6). Transmittances calculated with the IFS Fouquart and Bonnel (1980) clear-sky radiative transfer formulation, the Thomas and Stamnes (2002) two-stream approximation used for aerosol transmittance in hlradia and the Ritter and Geleyn (1992) two-stream approximation used in acraneb2 are compared to the transmittance from the accurate DISORT radiative transfer scheme (Stamnes et al., 1988) run using 30 streams. Figure $8 \mathrm{~b}$ shows the relative differences in transmittance between these radiative transfer schemes and DISORT. As can be seen from Fig. 8a and b, the IFS, hlradia and acraneb2 radiative transfer approximations give transmittances that are within a few percent of the accurate 30stream DISORT calculations for optical thicknesses less than 
(a)

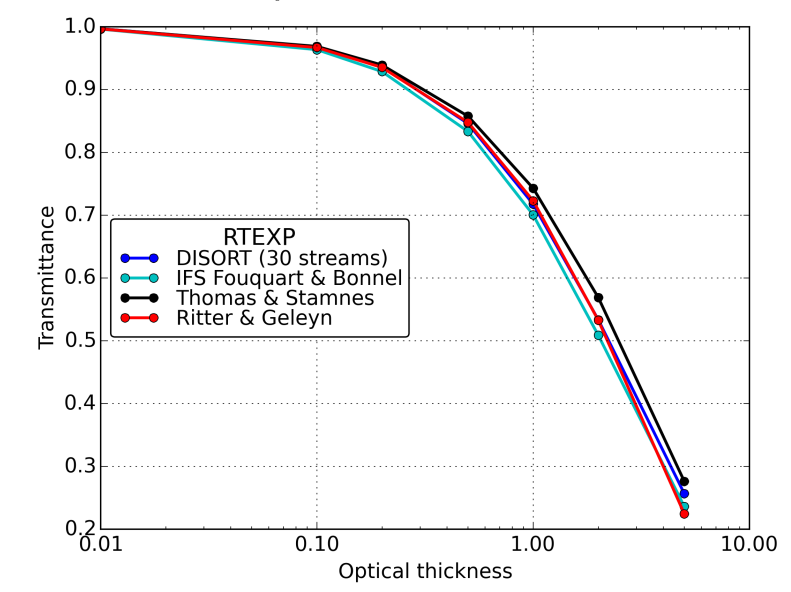

(b)

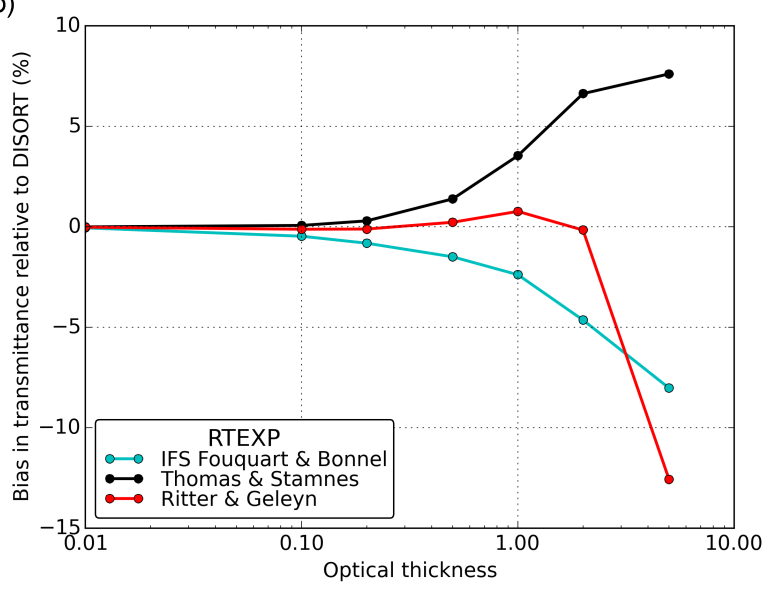

Figure 8. (a) Transmission as a function of optical depth through a homogeneous atmospheric layer containing aerosol ( $\mathrm{SSA}=0.95$, $g=0.7$, cosine of the solar zenith angle set to 0.6) for the following radiative transfer algorithms: IFS Fouquart and Bonnel (1980) clear-sky radiative transfer formulation (cyan curve), the Thomas and Stamnes (2002) two-stream approximation used for aerosol transmittance in hlradia (black curve), the Ritter and Geleyn (1992) two-stream approximation used in acraneb2 (red curve) and the accurate 30-stream DISORT (Stamnes et al., 1988) radiative transfer scheme (blue curve). Panel (b) is the same as panel (a) but shows the transmission differences relative to the accurate DISORT scheme.

1. Even for optical thicknesses of up to 5, the approximations remain within $\pm 13 \%$ of the DISORT results.

\section{Conclusions and future work}

We carried out single-column diagnostic experiments using the MUSC model and three radiation schemes (IFS, hlradia and acraneb2) to examine the influence of the direct radiative effects of aerosols on SW radiative flux. In particular, we focused on the effect of AOD550, aerosol IOPs, the relative humidity, vertical profile of AOD and the radiative transfer formulations on SW fluxes.

In the wildfire case study, we showed that the bias in modelled global SWD flux relative to observations was lowest when observed AOD550 and IOPs were included in the simulations (within $\pm 4 \%$ at midday). This was true irrespective of the radiation scheme and its spectral resolution. Global SWD flux was greatly overestimated, by more than $15 \%$ at midday, when aerosols were excluded and by $+10 \%$ at midday when the climatological aerosols were used (Tegen et al., 1997). On the other hand, global SWD irradiance was underestimated by $11 \%$ at noon, when observed AOD550 and parameterised IOPs, as opposed to observed IOPs, were used in the experiments. This highlights the need for accurate information on both aerosol concentration and aerosol IOPs in order to improve the simulated radiation budget in the model. The importance of all of the aerosol IOPs, and not just AOD550, in the direct radiative effect of aerosols on solar radiation was clearly demonstrated. The over- and under-estimation of global SWD flux leads to errors in model temperatures and energy fluxes. Therefore, during heavy pollution episodes the use of real-time aerosols would greatly improve the radiation budget and meteorological forecasts. The wildfire experiments also illustrate that the performance of the broadband hlradia and acraneb2 schemes is comparable to that of the spectral IFS scheme. The results attained for the three schemes were similar, with simulated global SWD fluxes mostly within $10-20 \mathrm{~W} \mathrm{~m}^{-2}$ of each other for each aerosol scenario.

The dependency of the direct radiative effect of aerosols on relative humidity was up to $\pm 6 \%$ for an AOD of 1.0. As a first approximation, assuming a constant relative humidity is acceptable but we suggest that relative-humidity-dependent parameterisations of aerosol IOPs should be used. The effect of the vertical profile of IFS land aerosols (via the vertical scale height) on net SW irradiance near the surface was found to be up to $4 \%$. This is consistent with the finding of Meloni et al. (2005). The influence of the vertical profile on modellevel SW heating rates was large, changing by up to a factor of 2 in the boundary layer in response to the aerosol vertical distribution. This highlights the need for using realistic vertical profiles of aerosols. In reality, aerosols are distributed in discrete rather than continuous layers. We investigated the influence of the vertical scale height on SW fluxes and heating rates. Non-exponential forms of the profile could also be tested. The IFS, hlradia and acraneb2 radiative transfer approximations were tested for a range of optical depths and found to be accurate to within $\pm 13 \%$ compared to the DISORT model, even for large aerosol loads.

The influence of improvements in the representation of the direct radiative effect of aerosols on meteorological forecasts needs further study using 3-D simulations. We plan to upgrade the aerosol climatology in the HARMONIE-AROME configuration of the ALADIN-HIRLAM system to the more realistic MACC reanalysis data set. We will also investigate 
the option of acquiring real-time aerosol input, including the vertical profile of the aerosol properties, from 3-D aerosol IOP estimates from the C-IFS model or chemical transport model simulations, possibly coupled to the NWP model. We also plan to carry out a similar study to the one presented here for all-sky fluxes.

Author contributions. The experiments were designed and run by Emily Gleeson, Velle Toll, Laura Rontu and Kristian Pagh Nielsen. Emily Gleeson prepared the manuscript with contributions from all co-authors.

Acknowledgements. We acknowledge the support of the International HIRLAM-B and ALADIN programmes. This work was also supported by research grant No. 9140 from the Estonian Science Foundation and by institutional research funding IUT20-11 from the Estonian Ministry of Education and Research. We would like to thank Erko Jakobson for his effort in maintaining the Tõravere AERONET site, which archives the aerosol data used in this study and Ain Kallis for his effort in maintaining the Toravere BSRN station, whose archived radiation data were used in this study. Finally, we would like to thank the two anonymous reviewers and the editor for their very useful feedback and comments which have helped to improve the paper significantly.

Edited by: B. Vogel

\section{References}

Anderson, G. P., Clough, S. A., Kneizys, F. X., Chetwynd, J. H., and Shettle, E. P.: AFGL Atmospheric Constituent Profiles (0$120 \mathrm{~km})$, Tech. Rep. AFGL-TR-86-0110, Air Force Geophysics Lab Hanscom AFB, MA, USA, 1986.

Baklanov, A., Schlünzen, K., Suppan, P., Baldasano, J., Brunner, D., Aksoyoglu, S., Carmichael, G., Douros, J., Flemming, J., Forkel, R., Galmarini, S., Gauss, M., Grell, G., Hirtl, M., Joffre, S., Jorba, O., Kaas, E., Kaasik, M., Kallos, G., Kong, X., Korsholm, U., Kurganskiy, A., Kushta, J., Lohmann, U., Mahura, A., Manders-Groot, A., Maurizi, A., Moussiopoulos, N., Rao, S. T., Savage, N., Seigneur, C., Sokhi, R. S., Solazzo, E., Solomos, S., Sørensen, B., Tsegas, G., Vignati, E., Vogel, B., and Zhang, Y.: Online coupled regional meteorology chemistry models in Europe: current status and prospects, Atmos. Chem. Phys., 14, 317-398, doi:10.5194/acp-14-317-2014, 2014.

Bangert, M., Nenes, A., Vogel, B., Vogel, H., Barahona, D., Karydis, V. A., Kumar, P., Kottmeier, C., and Blahak, U.: Saharan dust event impacts on cloud formation and radiation over Western Europe, Atmos. Chem. Phys., 12, 4045-4063, doi:10.5194/acp-124045-2012, 2012.

Bellouin, N., Boucher, O., Haywood, J., and Reddy, M. S.: Global estimate of aerosol direct radiative forcing from satellite measurements, Nature, 438, 1138-1141, 2005.

Bénard, P., Vivoda, J., Mašek, J., Smolíková, P., Yessad, K., Smith, C., Brozkova, R., and Geleyn, J. F.: Dynamical kernel of the Aladin-NH spectral limited-area model: Revised formulation and sensitivity experiments, Q. J. Roy. Meteor. Soc., 136, 155169, 2010.

Bian, H., Chin, M., Rodriguez, J. M., Yu, H., Penner, J. E., and Strahan, S.: Sensitivity of aerosol optical thickness and aerosol direct radiative effect to relative humidity, Atmos. Chem. Phys., 9, 2375-2386, doi:10.5194/acp-9-2375-2009, 2009.

Breitkreuz, H., Schroedter-Homscheidt, M., Holzer-Popp, T., and Dech, S.: Short-range direct and diffuse irradiance forecasts for solar energy applications based on aerosol chemical transport and numerical weather modeling, J. Appl. Meteorol. Clim., 48, 1766-1779, 2009.

Carmona, I., Kaufman, Y. J., and Alpert, P.: Using numerical weather prediction errors to estimate aerosol heating, Tellus B, 60, 729-741, 2008.

Cheng, Y. F., Wiedensohler, A., Eichler, H., Heintzenberg, J., Tesche, M., Ansmann, A., Wendisch, M., Su, H., Althausen, D., Herrmann, H., Gnauk, T., Brüggemann, E., Hu, M., and Zhang, Y. H.: Relative humidity dependence of aerosol optical properties and direct radiative forcing in the surface boundary layer at Xinken in Pearl River Delta of China: An observation based numerical study, Atmos. Environ., 42, 6373-6397, 2008.

Chubarova, N., Nezval', Ye., Sviridenkov, I., Smirnov, A., and Slutsker, I.: Smoke aerosol and its radiative effects during extreme fire event over Central Russia in summer 2010, Atmos. Meas. Tech., 5, 557-568, doi:10.5194/amt-5-557-2012, 2012.

Coakley Jr., J. A. and Chylek, P.: The two-stream approximation in radiative transfer: Including the angle of the incident radiation, $\mathrm{J}$. Atmos. Sci., 32, 409-418, 1975.

Cook, J. and Highwood, E. J.: Climate response to tropospheric absorbing aerosols in an intermediate general-circulation model, Q. J. Roy. Meteor. Soc., 130, 175-191, 2004.

Dubovik, O. and King, M. D.: A flexible inversion algorithm for retrieval of aerosol optical properties from Sun and sky radiance measurements, J. Geophys. Res.-Atmos. (1984-2012), 105, 20673-20696, 2000.

Dubovik, O., Holben, B. N., Eck, T. F., Smirnov, A., Kaufman, Y. J., King, M. D., Tanré, D., and Slutsker, I.: Variability of absorption and optical properties of key aerosol types observed in worldwide locations, J. Atmos. Sci., 59, 590-608, 2002.

ECMWF: 2.5 Input to the radiation scheme, available at: https: //software.ecmwf.int/wiki/display/IFS/CY28R1+Official+IFS+ Documentation?preview=/36537694/36733237/Physics.pdf (last access: 1 March 2016), 2004.

Faroux, S., Kaptué Tchuenté, A. T., Roujean, J.-L., Masson, V., Martin, E., and Le Moigne, P.: ECOCLIMAP-II/Europe: a twofold database of ecosystems and surface parameters at $1 \mathrm{~km}$ resolution based on satellite information for use in land surface, meteorological and climate models, Geosci. Model Dev., 6, 563582, doi:10.5194/gmd-6-563-2013, 2013.

Fouquart, Y. and Bonnell, B.: Computation of solar heating of the Earth's atmosphere: A new parameterization, Contrib. Atmos. Phys., 53, 35-62, 1980.

Grell, G. and Baklanov, A.: Integrated modeling for forecasting weather and air quality: A call for fully coupled approaches, Atmos. Environ., 45, 6845-6851, 2011.

Guibert, S., Matthias, V., Schulz, M., Bösenberg, J., Eixmann, R., Mattis, I., Pappalardo, G., Perrone, M. R., Spinelli, N., and Vaughan, G.: The vertical distribution of aerosol over Europe Synthesis of one year of EARLINET aerosol lidar measurements 
and aerosol transport modeling with LMDzT-INCA, Atmos. Environ., 39, 2933-2943, 2005.

Haywood, J. and Boucher, O.: Estimates of the direct and indirect radiative forcing due to tropospheric aerosols: A review, Rev. Geophys., 38, 513-543, 2000.

Hess, M., Koepke, P., and Schult, I.: Optical properties of aerosols and clouds: The software package OPAC, B. Am. Meteorol. Soc., 79, 831-844, 1998.

Holben, B. N., Eck, T. F., Slutsker, I., Tanré, D., Buis, J. P., Setzer, A., Vermote, E., Reagan, J. A., Kaufman, Y. J., Nakajima, T., and Lavenu, F.: AERONET - A federated instrument network and data archive for aerosol characterization, Remote Sens. Environ., 66, 1-16, 1998.

Huang, J., Fu, Q., Su, J., Tang, Q., Minnis, P., Hu, Y., Yi, Y., and Zhao, Q.: Taklimakan dust aerosol radiative heating derived from CALIPSO observations using the Fu-Liou radiation model with CERES constraints, Atmos. Chem. Phys., 9, 4011-4021, doi:10.5194/acp-9-4011-2009, 2009.

Huijnen, V., Flemming, J., Kaiser, J. W., Inness, A., Leitão, J., Heil, A., Eskes, H. J., Schultz, M. G., Benedetti, A., Hadji-Lazaro, J., Dufour, G., and Eremenko, M.: Hindcast experiments of tropospheric composition during the summer 2010 fires over western Russia, Atmos. Chem. Phys., 12, 4341-4364, doi:10.5194/acp12-4341-2012, 2012.

Inness, A., Baier, F., Benedetti, A., Bouarar, I., Chabrillat, S., Clark, H., Clerbaux, C., Coheur, P., Engelen, R. J., Errera, Q., Flemming, J., George, M., Granier, C., Hadji-Lazaro, J., Huijnen, V., Hurtmans, D., Jones, L., Kaiser, J. W., Kapsomenakis, J., Lefever, K., Leitão, J., Razinger, M., Richter, A., Schultz, M. G., Simmons, A. J., Suttie, M., Stein, O., Thépaut, J.-N., Thouret, V., Vrekoussis, M., Zerefos, C., and the MACC team: The MACC reanalysis: an 8 yr data set of atmospheric composition, Atmos. Chem. Phys., 13, 4073-4109, doi:10.5194/acp-13-4073-2013, 2013.

Jacobson, M. Z.: Strong radiative heating due to the mixing state of black carbon in atmospheric aerosols, Nature, 409, 695-697, 2001.

Joseph, J. H., Wiscombe, W. J., and Weinman, J. A.: The DeltaEddington approximation for radiative flux transfer, J. Atmos. Sci., 33, 2452-2459, 1976.

Kallis, A.: Basic and other measurements of radiation at station Toravere (2010-08), Tartu Observatoorium, Toravere, doi:10.1594/PANGAEA.745066, 2010.

Kinne, S., O’Donnel, D., Stier, P., Kloster, S., Zhang, K., Schmidt, H., Rast, S., Giorgetta, M., Eck, T. F., and Stevens, B.: MAC-v1: A new global aerosol climatology for climate studies, Journal of Advances in Modeling Earth Systems, 5, 704-740, 2013.

Koepke, P., Hess, M., Schult, I., and Shettle, E. P.: Global Aerosol Data Set, Report No. 243, Max-Planck-Institut für Meteorologie, Hamburg, Germany, ISSN 0937-1060, 1997.

Loeb, N. G. and Manalo-Smith, N.: Top-of-atmosphere direct radiative effect of aerosols over global oceans from merged CERES and MODIS observations, J. Climate, 18, 3506-3526, 2005.

Lindstedt, D., Lind, P., Kjellström, E., and Jones, C.: A new regional climate model operating at the meso-gamma scale: performance over Europe, Tellus A, 67, 24138, doi:10.3402/tellusa.v67.24138, 2015.

Magi, B. I. and Hobbs, P. V.: Effects of humidity on aerosols in southern Africa during the biomass burning season, J. Geophys. Res.-Atmos. (1984-2012), 108, 8495, doi:10.1029/2002JD002144, 2003.

Malardel, S., Lac, C., Pinty, J.-P., Thouron, O., Bouteloup, Y., Bouyssel, F., Seity, Y., and Nuissier, O.: Representation of clouds in AROME, in: Proceedings of the ECMWF Workshop on parametrization of clouds in large-scale models, ECMWF, 1315 November 2006, Reading, UK, 2006.

Markowicz, K. M., Flatau, P. J., Quinn, P. K., Carrico, C. M., Flatau, M. K., Vogelmann, A. M., Bates, D., Liu, M., and Rood, M. J.: Influence of relative humidity on aerosol radiative forcing: An ACE-Asia experiment perspective, J. Geophys. Res.-Atmos. (1984-2012), 108, 8662, doi:10.1029/2002JD003066, 2003.

Mascart, P. J. and Bougeault, P.: The Meso-NH atmospheric simulation system: Scientific documentation, Tech. rep., Meteo France, Toulouse, France, 2011.

Mašek, J., Geleyn, J.-F., Brožková, R., Giot, O., Achom, H. O., and Kuma, P.: Single interval shortwave radiation scheme with parameterized optical saturation and spectral overlaps, Q. J. Roy. Meteor. Soc., 142, 304-326, doi:10.1002/qj.2653, 2016.

Masson, V., Le Moigne, P., Martin, E., Faroux, S., Alias, A., Alkama, R., Belamari, S., Barbu, A., Boone, A., Bouyssel, F., Brousseau, P., Brun, E., Calvet, J.-C., Carrer, D., Decharme, B., Delire, C., Donier, S., Essaouini, K., Gibelin, A.-L., Giordani, H., Habets, F., Jidane, M., Kerdraon, G., Kourzeneva, E., Lafaysse, M., Lafont, S., Lebeaupin Brossier, C., Lemonsu, A., Mahfouf, J.-F., Marguinaud, P., Mokhtari, M., Morin, S., Pigeon, G., Salgado, R., Seity, Y., Taillefer, F., Tanguy, G., Tulet, P., Vincendon, B., Vionnet, V., and Voldoire, A.: The SURFEXv7.2 land and ocean surface platform for coupled or offline simulation of earth surface variables and fluxes, Geosci. Model Dev., 6, 929-960, doi:10.5194/gmd-6-929-2013, 2013.

Matthias, V., Balis, D., Bösenberg, J., Eixmann, R., Iarlori, M., Komguem, L., Mattis, I., Papayannis, A., Pappalardo, G., Perrone, M. R., and Wang, X.: Vertical aerosol distribution over Europe: Statistical analysis of Raman lidar data from 10 European Aerosol Research Lidar Network (EARLINET) stations, J. Geophys. Res.-Atmos., 109, D18201, doi:10.1029/2004JD004638, 2004.

Mayer, B. and Kylling, A.: Technical note: The libRadtran software package for radiative transfer calculations - description and examples of use, Atmos. Chem. Phys., 5, 1855-1877, doi:10.5194/acp-5-1855-2005, 2005.

Meloni, D., Di Sarra, A., Di Iorio, T., and Fiocco, G.: Influence of the vertical profile of Saharan dust on the visible direct radiative forcing, J. Quant. Spectrosc. Ra., 93, 397-413, 2005.

Milton, S. F., Greed, G., Brooks, M. E., Haywood, J., Johnson, B., Allan, R. P., Slingo, A., and Grey, W. M. F.: Modeled and observed atmospheric radiation balance during the West African dry season: Role of mineral dust, biomass burning aerosol, and surface albedo, J. Geophys. Res.-Atmos. (1984-2012), 113, D00C02, doi:10.1029/2007JD009741, 2008.

Morcrette, J. J.: Radiation and cloud radiative properties in the European Centre for Medium Range Weather Forecasts forecasting system, J. Geophys. Res., 96, 9121-9132, doi:10.1029/89JD01597, 1991.

Morcrette, J. J., Benedetti, A., Ghelli, A., Kaiser, J. W., and Tompkins, A. M.: Aerosol-cloud-radiation interactions and their impact on ECMWF/MACC forecasts, European Centre for 
Medium-Range Weather Forecasts, ECMWF, Reading, UK, 2011.

Mulcahy, J. P., Walters, D. N., Bellouin, N., and Milton, S. F.: Impacts of increasing the aerosol complexity in the Met Office global numerical weather prediction model, Atmos. Chem. Phys., 14, 4749-4778, doi:10.5194/acp-14-4749-2014, 2014.

Myhre, G., Shindell, D., Bréon, F. M., Collins, W., Fuglestvedt, J., Huang, J., Koch, D., Lamarque, J.-F., Lee, D., Mendoza, B., Nakajima, T., Robock, A., Stephens, G., Takemura, T., and Zhang, H.: Climate change 2013: the physical science basis. Contribution of Working Group I to the Fifth Assessment Report of the Intergovernmental Panel on Climate Change, edited by: Stocker, T. F., Qin, D., Plattner, G.-K., Tignor, M., Allen, S. K., Boschung, J., Nauels, A., Xia, Y., Bex, V., and Midgley, P. M., Cambridge University Press Cambridge, UK and New York, NY, USA, 2013.

Ohmura, A., Gilgen, H., Hegner, H., Müller, G., Wild, M., Dutton, E. G., Forgan, B., Fröhlich, C., Philipona, R., Heimo, A., and König-Langlo, G.: Baseline Surface Radiation Network (BSRN/WCRP): New precision radiometry for climate research, B. Am. Meteorol. Soc., 79, 2115-2136, 1998.

Palamarchuk, I., Ivanov, S., Ruban, I., and Pavlova, H.: Influence of aerosols on atmospheric variables in the HARMONIE model, Atmos. Res., 169, 539-546, 2016.

Pilinis, C., Pandis, S. N., and Seinfeld, J. H.: Sensitivity of direct climate forcing by atmospheric aerosols to aerosol size and composition. J. Geophys. Res.-Atmos. (1984-2012), 100, 1873918754, 1995.

Pottier, P.: Overview of the operational configurations, ALADINHIRLAM Newsletter, 6, 123-128, 2016.

Räisänen P.: Two-stream approximations revisited: A new improvement and tests with GCM data, Q. J. Roy. Meteor. Soc., 128, 2397-2416, doi:10.1256/qj.01.161, 2002.

Reale, O., Lau, K. M., and da Silva, A.: Impact of interactive aerosol on the African Easterly Jet in the NASA GEOS-5 global forecasting system, Weather Forecast., 26, 504-519, 2011.

Ritter, B. and Geleyn, J. F.: A comprehensive radiation scheme for numerical weather prediction models with potential applications in climate simulations, Mon. Weather Rev., 120, 303-325, doi:10.1175/1520-0493(1992)120<0303:ACRSFN>2.0.CO;2, 1992.

Rodwell, M. J. and Jung, T.: Understanding the local and global impacts of model physics changes: An aerosol example, Q. J. Roy. Meteor. Soc., 134, 1479-1497, 2008.

Savijärvi, H.: Fast Radiation Parameterization Schemes for Mesoscale and Short-Range Forecast Models, J. Appl. Meteorol., 29, 437-447, doi:10.1175/15200450(1990)029<0437:FRPSFM>2.0.CO;2, 1990.

Seity, Y., Brousseau, P., Malardel, S., Hello, G., Bénard, P., Bouttier, F., Lac, C., and Masson, V.: The AROME-France convectivescale operational model, Mon. Weather Rev., 139, 976-991, 2011.

Slutsker, I. and Kinne, S.: Wavelength dependence of the optical depth of biomass burning, urban, and desert dust aerosols, J. Geophys. Res., 104, 31333-31349, doi:10.1029/1999JD900923, 1999.

Smirnov, A., Holben, B. N., Eck, T. F., Dubovik, O., and Slutsker, I.: Cloud-screening and quality control algorithms for the
AERONET database, Remote Sens. Environ., 73, 337-349, 2000.

Stamnes, K., Tsay, S.-C., Wiscombe, W., and Jayaweera, K.: Numerically stable algorithm for discrete-ordinate-method radiative transfer in multiple scattering and emitting layered media, Appl. Optics, 27, 2502-2509, 1988.

Takemura, T., Nozawa, T., Emori, S., Nakajima, T. Y., and Nakajima, T.: Simulation of climate response to aerosol direct and indirect effects with aerosol transport-radiation model, J. Geophys. Res.-Atmos., 110, D02202, doi:10.1029/2004JD005029, 2005.

Tanré, D., Geleyn, J. F., and Slingo, J.: First results of the introduction of an advanced aerosol-radiation interaction in the ECMWF low resolution global model, in: Aerosols and their climatic effects, edited by: Gerber, H. E. and Deepak, A., A. Deepak Publishing, Hampton, Va, USA, 133-177, 1984.

Tegen, I., Hollrig, P., Chin, M., Fung, I., Jacob, D., and Penner, J.: Contribution of different aerosol species to the global aerosol extinction optical thickness: Estimates from model results, J. Geophys. Res.-Atmos. (1984-2012), 102, 23895-23915, 1997.

Thomas, G. E. and Stamnes, K.: Radiative Transfer in the Atmosphere and Ocean, Cambridge University Press, New York, NY, USA, 2002.

Toll, V. and Männik, A.: The direct radiative effect of wildfire smoke on a severe thunderstorm event in the Baltic Sea region, Atmos. Res., 155, 87-101, 2015.

Toll, V., Männik, A., Luhamaa, A., and Rõõm, R.: Hindcast experiments of the derecho in Estonia on 8 August, 2010: Modelling derecho with NWP model HARMONIE, Atmos. Res., 158, 179191, 2015a.

Toll, V., Reis, K., Ots, R., Kaasik, M., Männik, A., Prank, M., and Sofiev, M.: SILAM and MACC reanalysis aerosol data used for simulating the aerosol direct radiative effect with the NWP model HARMONIE for summer 2010 wildfire case in Russia, Atmos. Environ., 121, 75-85, doi:10.1016/j.atmosenv.2015.06.007, 2015b.

Toll, V., Gleeson, E., Nielsen, K. P., Männik, A., Mašek, J., Rontu, L., and Post, P.: Impacts of the direct radiative effect of aerosols in numerical weather prediction over Europe using the ALADIN-HIRLAM NWP system, Atmos. Res., 172-173, 163173, doi:10.1016/j.atmosres.2016.01.003, 2016.

Tompkins, A. M., Cardinali, C., Morcrette, J. J., and Rodwell, M.: Influence of aerosol climatology on forecasts of the African Easterly Jet, Geophys. Res. Lett., 32, L10801, doi:10.1029/2004GL022189, 2005.

USGS: GTOPO30, Global 30 Arc Second Elevation Data Set, US Geological Survey Earth Resources Observation and Science (EROS) Center, Reston, VA, USA, 1998.

Vogel, B., Vogel, H., Bäumer, D., Bangert, M., Lundgren, K., Rinke, R., and Stanelle, T.: The comprehensive model system COSMOART - Radiative impact of aerosol on the state of the atmosphere on the regional scale, Atmos. Chem. Phys., 9, 8661-8680, doi:10.5194/acp-9-8661-2009, 2009.

Wang, C.: A modeling study on the climate impacts of black carbon aerosols, J. Geophys. Res.-Atmos., 109, D03106, doi:10.1029/2003JD004084, 2004.

White, P. W.: IFS documentation (CY23R4), part IV: Physical processes, ECMWF, Reading, UK, 2004.

Witte, J. C., Douglass, A. R., da Silva, A., Torres, O., Levy, R., and Duncan, B. N.: NASA A-Train and Terra observations of 
the 2010 Russian wildfires, Atmos. Chem. Phys., 11, 9287-9301, doi:10.5194/acp-11-9287-2011, 2011.

Yu, H., Kaufman, Y. J., Chin, M., Feingold, G., Remer, L. A., Anderson, T. L., Balkanski, Y., Bellouin, N., Boucher, O., Christopher, S., DeCola, P., Kahn, R., Koch, D., Loeb, N., Reddy, M. S., Schulz, M., Takemura, T., and Zhou, M.: A review of measurement-based assessments of the aerosol direct radiative effect and forcing, Atmos. Chem. Phys., 6, 613-666, doi:10.5194/acp-6-613-2006, 2006.

Zamora, R. J., Dutton, E. G., Trainer, M., McKeen, S. A., Wilczak, J. M., and Hou, Y. T.: The accuracy of solar irradiance calculations used in mesoscale numerical weather prediction, Mon. Weather Rev., 133, 783-792, 2005.
Zhang, Y.: Online-coupled meteorology and chemistry models: history, current status, and outlook, Atmos. Chem. Phys., 8, 28952932, doi:10.5194/acp-8-2895-2008, 2008.

Zieger, P., Fierz-Schmidhauser, R., Weingartner, E., and Baltensperger, U.: Effects of relative humidity on aerosol light scattering: results from different European sites, Atmos. Chem. Phys., 13, 10609-10631, doi:10.5194/acp-13-10609-2013, 2013. 